\title{
NERIMO IR DEPRESIJOS SIMPTOMŲ RAIŠKA, SERGANT ÜMINIU MIOKARDO INFARKTU
}

\author{
Diana Bukauskaitė ${ }^{1}$, Anelè Brazaitytè ${ }^{1}$, Virginija Adomaitiené $\dot{e}^{2}$ \\ ${ }^{1}$ Lietuvos sveikatos mokslu universiteto Medicinos fakultetas, \\ ${ }^{2}$ Lietuvos sveikatos mokslu universiteto Psichiatrijos klinika
}

Raktažodžiai: ūminis miokardo infarktas, depresijos simptomai, nerimo simptomai, lytis, gyvenimo kokybè.

\begin{abstract}
Santrauka
Tikslas. Nustatyti nerimo ir depresijos paplitimą tarp pacientų, sirgusių ūminiu miokardo infarktu (MI), ir šių simptomų dažnị, priklausomai nuo lyties. Tyrimo metodai. Depresijos ir nerimo simptomai vertinti pacientų apklausos būdu, naudojant standartizuotą Hospitalinę nerimo ir depresijos skalę (angl. Hospital Anxiety and Depression scale, HADS). Vertinti tiriamujų amžių bei lytị naudotas autorių sudarytas sociodemografinis klausimynas. Statistinè duomenu analizè atlikta naudojant SPSS 20 ir Microsoft Office Excel 2010. Gautujų duomenų statistinis patikimumo lygmuo pasirinktas 0,05 .

Rezultatai. Iš visų persirgusių MI, 55 proc. neturejo nei nerimo, nei depresijos simptomų. 32 proc. turejo nerimo ar depresinių sutrikimų, 13 proc. nustatyta ir nerimui, ir depresijai būdingų požymių. Nerimo simptomai nustatyti 23,97 proc. vyrų ir 32,69 proc. moterų. Depresiniai sutrikimai stebėti 4,80 proc. vyru ir 7,69 proc. moterų. Abiejų sutrikimų simptomų turejjo 10,27 proc. vyrų ir 21,20 proc. moterų, neturèjo $-60,96$ proc. vyru ir 38,46 proc. moterų.

Išvados. Nustatyta, kad 45 proc. persirgusių MI pacientų turi nerimo ir(ar) depresijos simptomų. Depresijos ir nerimo simptomai statistiškai reikšmingai susiję su asmens lytimi.
\end{abstract}

\section{Ivadas}

Daugelio pasaulio šalių sveikatos sistemų dėmesys sutelktas į didžiausią mirštamumą sukeliančias širdies ir kraujagyslių ligas (ŠKLL). Viena iš tokių - MI, dažnai vadinamas širdies smūgiu, - tai širdies raumens ląstelių žūtis dèl užsitęsusio išemijos periodo [1]. Ši patologija dažniausiai aiškinama trombų formavimusi, tačiau svarbus ir kraujotakos disbalansas - per mažas miokardo aprūpinimas krauju (staigus arterinio kraujospūdžio kritimas) ar padidèjęs aprūpinimo poreikis (ryškus širdies susitraukimų dažnio padidejjimas) [2].

MI - pagrindinè mirties ir neịgalumo priežastis pasauliniu mastu [1]. Higienos instituto duomenimis, $2018 \mathrm{~m}$. sergančiujų MI skaičius Lietuvoje 1000 gyventojų siekè 3,29 [3].

MI sergančiųju gyvenimo kokybė prastesnè: liga veikia fizinę, psichinę ir socialinę asmens gerovę. Pacientų po MI gyvenimo kokybè retai išlieka tokia pat, kaip prieš ligą [4], ji tampa žemesnè, lyginant su bendraja populiacijos gyvenimo kokybe [5].

Kalbant apie MI patogenezę, vis dažniau akcentuojami ir nuotaikos (afektiniai) sutrikimai. JAV nacionalinis ligų kontrolès ir prevencijos centras pastebejjo sergančiųų MI padidejjusią psichikos ligų riziką [6]. Nustatyta, kad depresija ir nerimas bei išemine širdies liga statistiškai reikšmingai vystosi kartu [7]. Nuotaikos sutrikimų svarbiausi požymiai yra afektiniai pokyčiai arba nuotaikos kaita. Šie sutrikimai daro itakos asmens veiklai, mąstymui, aplinkos suvokimui. Nuotaikos sutrikimą paprastai lydi ir visų aktyvumo lygių pakitimai [8]. Lietuvoje šių ligų paplitimas taip pat didelis - 16,53/1000 gyventojų [3]. Atsižvelgiant ị statistinius Higienos instituto duomenis, psichikos ir elgesio sutrikimais Lietuvoje dažniau serga moterys (vyrų ir moterų sergamumas 100 tūkst. gyv. 2017 m. Lietuvoje buvo 239 ir 703), tačiau MI dažniau patiria vyrai (vyrų ir moterų sergamumas 100 tūkst. gyv. 2017 m. Lietuvoje buvo 219 ir 124).

Tyrimo tikslas: nustatyti nerimo ir depresijos paplitimą tarp pacientų, sirgusių ūminiu MI, ir šių simptomų dažnį, priklausomai nuo lyties.

\section{Tyrimo objektas ir metodai}

Tyrimas buvo vykdomas Lietuvos sveikatos mokslų universiteto (LSMU) ligoninès Kauno klinikų Kardiologijos klinikoje. Apklausti 198 stacionaro pacientai, gydomi po ivykusio MI (TLK-10-AM I21.0-3).

Apklausa pradèta gavus LMSU Bioetikos centro leidimą 
(protokolo Nr. BEC-MF-239, išdavimo data - 2017-01-25). Pacientai pasirinkti atsitiktinès atrankos būdu. Buvo naudojama kodavimo sistema, siekiant užtikrinti tiriamųjų konfidencialumą.

Depresijos ir nerimo simptomai vertinti, naudojant HADS. Skalę sudaro 14 klausimų, kurių pagalba vertinama, ar pacientas turi nerimo ir(ar) depresijos simptomų, ar abu simptomai reiškèsi savaitės laikotarpiu. Vertinti tiriamujų amžių bei lytị naudotas autorių sudarytas sociodemografinis klausimynas. Statistinè duomenų analizè atlikta naudojant SPSS 20 ir Microsoft Office Excel 2010. Gautų duomenu statistinis patikimumo lygmuo pasirinktas 0,05 .

\section{Tyrimo rezultatai}

Tyrime dalyvavo 198 tiriamieji, iš jų 146 (73,7 proc.) vyrai ir 52 (26,3 proc.) moterys. Bendrasis tiriamujų amžiaus vidurkis 64 metai: vyrų - 61, moterų - 74. Tarp visų persirgusių MI 55 proc. neturèjo nei nerimo, nei depresijos simptomų. 32 proc. turejjo nerimo ar depresinį sutrikimą, 13 proc. turèjo ir nerimui, ir depresijai būdingų požymių.

Analizuojant tiriamuosius pagal lytị, simptomų neturejjo 60,96 proc. vyrų ir 38,46 proc. moterų. Rasta, kad vyrų ir moterų nerimo ir depresijos paplitimas skiriasi. Nerimo simptomai nustatyti 23,97 proc. vyrų ir 32,69 proc. moterų. Depresiniai sutrikimai stebimi rečiau, dažniau moterims $(4,80$ proc. vyrų ir 7,69 proc. moterų). Abiejų sutrikimų simptomai nustatyti 10,27 proc. vyrų ir 21,20 proc. moterų (1 lentelè).

\section{Diskusija}

Tiriant nerimo ir depresijos paplitimą, nustatyta, kad šių simptomų dažnis siekia net 45 proc. nuo visų MI persirgusių pacientų. Akivaizdi nuotaikos sutrikimų ir MI sąsaja skatina tolesnius tyrimus: ar nuotaikos sutrikimai yra reikšmingas MI rizikos veiksnys? Ar nuotaikos sutrikimai po MI predisponuoja atkrytit?

Depresiją, kaip MI rizikos veiksni, nurodo 19 studijų aprèpianti metaanalizè [9]: depresija 31 proc. susijusi su padidejusia MI rizika ir 36 proc. - su koronarine mirtimi. Nors tikslus mechanizmas, kaip depresija susijusi su MI atsiradimu, neišaiškintas, tyrime aptariami ịvairūs veiksniai. Pirmiausia, tai gali lemti biologiniai mechanizmai: uždegimas, trombocitų reaktyvumas, autonominès sistemos disreguliacija, miego ciklo sutrikimai, cirkadinio ritmo sutrikimai ir kt. [10]. Kalbama ir apie bendruosius depresijos ir širdies bei kraujagyslių ligų rizikos veiksnius, tokius kaip rūkymas, per didelis alkoholio vartojimas, fizinio aktyvumo trūkumas [11-13]. Depresija ir MI susiję su daugeliu tų pačių šalutinių ligų: nutukimas, diabetas, hipertenzija [9]. Vis dèlto, yra šaltiniu [14], kuriuose skelbiami kontraversiški duomenys: nerimo ir depresijos balai sergantiesiems nustatyti nedideli
1 lentelè. Nerimo ir depresijos simptomų raiška pagal lytị.

\begin{tabular}{|c|c|c|c|}
\hline \multirow[t]{2}{*}{ Simptomai } & \multicolumn{2}{|c|}{$\begin{array}{c}\text { Dažnis pagal lytị } \\
\text { (abs. ir \%) }\end{array}$} & \multirow{2}{*}{$\underset{\text { reikšmė }}{\mathbf{P}}$} \\
\hline & vyr. & mot. & \\
\hline Nèra & $89(60,96)$ & $20(38,46)$ & \multirow{4}{*}{$<0,034$} \\
\hline Nerimas & $35(23,97)$ & $17(32,69)$ & \\
\hline Depresija & $7(4,80)$ & $4(7,69)$ & \\
\hline Nerimas ir depresija & $15(10,27)$ & $11(21,20)$ & \\
\hline Iš viso: & $146(74)$ & $52(26)$ & \\
\hline
\end{tabular}

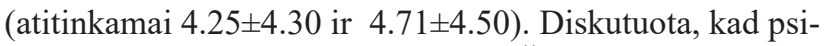
chinès būklès pokyčius lemia ne pati ŠKL, o ja sergančiujuc šalutinès ligos: arterinè hipertenzija, cukrinis diabetas, inkstų ligos. Šis nedidelès apimties (108 sergantieji ŠKL) tyrimas parodo, kad svarbu atsižvelgti ir ị kitas lètines, gyvenimo kokybę keičiančias, ligas.

Kalbant apie naujo kardiologinio ịvykio atsiradimą, nustatyta, kad pacientams, sveikstantiems po MI, kuriems kliniškai diagnozuota depresija, 2,00-2,5 karto didesnè naujo kardiologinio įvykio bei kardiologinès mirties rizika $[15,16]$. Nepaisant to, asmenų, besigydančių depresiją, ir neturinčiujų depresijos simptomų, vienerių metų mirštamumas nesiskiria [17].

LSMU Kardiologijos klinikoje vykdytame tyrime moteru nerimo ir depresijos simptomų paplitimas didesnis. Panašūs tyrimai ịrodo, kad tarp jaunų ūmiu MI sergančių moterų esamosios ir ankstesnès depresijos simptomų paplitimas didesnis, lyginant su vyrais $[18,19]$.

\section{Praktinès rekomendacijos}

1. Konsultacijos metu visiems MI sergantiems pacientams atlikti pirminį psichikos ištyrimą.

2. Atidžiau vertinti moterų, sergančiu MI, psichinę būklę, kadangi joms dažnesni nuotaikos sutrikimai.

3. Atkreipti dèmesi i Europos kardiologų draugijos MI gydymo gaires (2017 ESC Guidelines for the management of acute myocardial infarction in patients presenting with STEMI), kuriose siūloma ị reabilitacijos procesą ịtraukti psichologinę paramą (I, A lygio rekomendacija).

\section{Išvados}

1. Nustatyta, kad 45 proc. visų persirgusių MI pacientų turi nerimo ir(ar) depresijos simptomų.

2. Depresijos ir nerimo simptomai, sergant MI, statistiškai reikšmingai susiję su asmens lytimi: abiejų sutrikimų simptomai dažnesni moterims.

\section{Literatūra}

1. Thygesen K, Alpert JS, Jaffe AS, Chaitman BR, Bax JJ, Morrow DA, et al. Fourth universal definition of myocardial infarction. 
Eur Heart J 2018;40(3):237-69.

https://doi.org/10.1093/eurheartj/ehy462

2. Saleh M, Ambrose JA. Understanding myocardial infarction. F1000 Research 2018;7. https://doi.org/10.12688/f1000research.15096.1

3. Higienos institutas. Sergančių asmenų skaičius pagal diagnozių grupes. https://stat.hi.lt/default.aspx?report_id $=168$.

4. Wang W, Thompson DR, Ski CF, Liu M. Health-related quality of life and its associated factors in Chinese myocardial infarction patients. Eur J Prev Cardiol 2014;21(3):321-9. https://doi.org/10.1177/2047487312454757

5. Sakai M, Nakayama T, Shimbo T, Ueshima K, Kobayashi N, Izumi $\mathrm{T}$, et al. Post-discharge depressive symptoms can predict quality of life in AMI survivors: a prospective cohort study in Japan. Int J Cardiol 2011;146(3):379-84. https://doi.org/10.1016/j.ijcard.2009.07.017

6. CDC. Mental Health and Chronic Diseases CDC Fact Sheet. 2012. https:/www.cdc.gov/workplacehealthpromotion/toolsresources/pdfs/issue-brief-no-2-mental-health-and-chronicdisease.pdf

7. Kala P, Hudakova N, Jurajda M, Kasparek T, Ustohal L, Parenica $\mathrm{J}$, et al. Depression and anxiety after acute myocardial infarction treated by primary PCI. PLoS One 2016;11(4):e0152367. https://doi.org/10.1371/journal.pone.0152367

8. TLK-10-AM Sisteminis ligų sąrašas. 2015. http://ebook.vlk. lt/e.vadovas/index.jsp?topic=/lt.webmedia.vlk.drg.icd.ebook. content/html/icd/ivadas.html.

9. Wu Q, Kling JM. Depression and the risk of myocardial infarction and coronary death: a metaanalysis of prospective cohort studies. Medicine 2016;95(6):e2815. https://doi.org/10.1097/MD.0000000000002815

10. Lichtman JH, Bigger JT, Blumenthal JA, Frasure-Smith N, Kaufmann PG, Lespérance F, et al. Depression and coronary heart disease. Circulation 2008;118(17):1768-75. https://doi.org/10.1161/CIRCULATIONAHA.108.190769

11. Swenson JR. Quality of life in patients with coronary artery disease and the impact of depression. Curr Psychiatry Rep 2004;6(6):438-45. https://doi.org/10.1007/s11920-004-0008-x

12. Ruo B, Rumsfeld JS, Hlatky MA, Liu H, Browner WS, Whooley MA. Depressive symptoms and health-related quality of life. JAMA 2003;290(2):215. https://doi.org/10.1001/jama.290.2.215

13. Stein MB, Cox BJ, Afifi TO, Belik SL, Sareen J. Does comorbid depressive illness magnify the impact of chronic physical illness? A population-based perspective. Psychol Med 2006;36(05):587. https://doi.org/10.1017/S0033291706007239

14. Eng HS, Yean LC, Das S, Letchmi S, Yee KS, Bakar RA, et al. Anxiety and depression in patients with coronary heart disease: a study in a tertiary hospital. Iran J Med Sci 2011;36(3):201-6. 15. Topic R, Milicic D, Stimac Z, Loncar M, Velagic V, Marcinko D, et al. Somatic comorbidity, metabolic syndrome, cardiovascular risk, and CRP in patients with recurrent depressive disorders. Croat Med J 2013;54(5):453-9.

https://doi.org/10.3325/cmj.2013.54.453

16. von Känel R, Begré S. Depression after myocardial infarction. J Am Coll Cardiol 2006; 48(11):2215-7.

https://doi.org/10.1016/j.jacc.2006.09.007

17. Smolderen KG, Buchanan DM, Gosch K, Whooley M, Chan PS, Vaccarino V, et al. Depression treatment and 1-year mortality after acute myocardial infarction: insights from the TRIUMPH registry. Circulation 2017;135(18):1681-9.

https://doi.org/10.1161/CIRCULATIONAHA.116.025140

18. Feng HP, Chien WC, Cheng WT, Chung CH, Cheng SM, Tzeng WC. Risk of anxiety and depressive disorders in patients with myocardial infarction: a nationwide population-based cohort study. Medicine 2016;95(34):e4464. https://doi.org/10.1097/MD.0000000000004464

19. Smolderen KG, Strait KM, Dreyer RP, D'Onofrio G, Zhou S, Lichtman JH, et al. Depressive symptoms in younger women and men with acute myocardial infarction: insights from the VIRGO study. J Am Heart Assoc 2015;4(4).

https://doi.org/10.1161/JAHA.114.001424

\section{ANXIETY AND DEPRESSION SYMPTOMS IN PATIENTS WITH ACUTE MYOCARDIAL INFARCTION \\ D. Bukauskaitè, A. Brazaitytè, V. Adomaitienè}

Keywords: acute myocardial infarction, depression, anxiety, gender, medical outcomes, life quality.

Summary

Aim. To evaluate the prevalence of anxiety and depression symptoms between patients that had a myocardial infarction (MI). To test weather there is a significant link between MI patients' gender and symptoms of anxiety or depresion. Methods. To evaluate the symptoms of anxiety and depression, the standardised questionnaire "hospital anxiety and depression scale (HADS)" was used. To determine the gender and age, the authors" made sociodemographic questionnaire was used. Statistical analysis was made using SPSS20 and Microsoft Office Excel 2010. All results have statistical significance, as the $\mathrm{p}$ value is lower than 0.05 . Results. Anxiety or depression symptoms were present in 32 percent of all surveyed, 13 percent had symptoms of both psychiatric disorders and 55 percent had none of the symptoms. Anxiety symptoms were present in 23.97 percent of males and 32.69 percent of females. While 4.80 percent of males and 7.69 percent of females had symptoms of depression. Symptoms of both disorders had 10.27 percent of males and 21.20 percent of females. None of symptoms had 60.96 percent of males and 38.46 percent of females. Conclusions. The research revealed that 45 percent of all patients have anxiety and/ or depression symptoms. These disorders' symptoms are statistically related to the gender of a patient.

Correspondence to: aabrazaityte@gmail.com

Gauta 2019-09-26 